\title{
Investigating Young Male and Female Road Users' Behaviour as Pedestrians and Drivers
}

\section{Genç Erkek ve Kadın Yol Kullanıcılarının Yaya ve Sürücü Davranışları Arasındaki İlişskinin Araştırılması}

\author{
İbrahim Öztürk ${ }^{1}$, Bahar Öz² $\odot$
}

${ }^{1}$ Research Assistant, Middle East Technical University, Department of Psychology, Ankara, Turkey

${ }^{2}$ Assoc. Dr., Middle East Technical University, Department of Psychology, Ankara, Turkey

ORCID: I.Ö. 0000-0002-5113-1225

B.Ö. 0000-0001-5440-0948

\section{Corresponding author/Sorumlu yazar:} İbrahim Öztürk,

Middle East Technical University, Department of Psychology, Ankara, Turkey

E-mail/E-posta: ozturki@metu.edu.tr

Submitted/Başvuru: 08.04.2020

Accepted/Kabul: 22.01.2021

Citation/Atıf: Ozturk, l., \& Oz, B. (2021). Investigating young male and female road users' behaviour as pedestrians and drivers. Psikoloji Çalışmaları - Studies in Psychology, 41(2), 581-614.

https://doi.org/10.26650/SP2020-0045

\begin{abstract}
Young road users constitute one of the most vulnerable groups in terms of experiencing road traffic accidents as either drivers or pedestrians. Pedestrian and driver behaviours are important predictors of the road users' safety. The present study mainly aims to investigate the relationship between behaviours of young male and female road users as drivers and pedestrians. A total number of 573 young road users (316 male, 257 female) aged from 19 to 28 ( $M=22.2$, $S D=1.77)$ participated in the present study. Participants were requested to fill out a questionnaire package including demographic information form as well as the Pedestrian Behaviour Scale (PBS), the Driver Behaviour Questionnaire (DBQ) and the Positive Driver Behaviours Scale (PDBS). In line with the aims of the present study, first, the factor structure of the Pedestrian Behaviour Scale was investigated. Following that, gender differences in pedestrian and driver behaviours were examined. In terms of gender difference, males showed more pedestrian transgressions, pedestrian aggressive violations, driver aggressive violations, driver ordinary violations and fewer driver lapses compared to females. Moreover, aberrant pedestrian behaviours were positively related to aberrant driver behaviour, whereas positive pedestrian behaviours were negatively associated with aberrant driver behaviour. While pedestrian lapses and aggressive violations were negatively related to positive driver behaviours, pedestrian transgression and positive pedestrian behaviours were positively associated with positive driver behaviours. Overall, the results indicated that young road users who expressed more aberrant pedestrian behaviours also showed more aberrant driver behaviours. The results were discussed in relation to the administration of countermeasures against aberrant driver behaviours. Considering the consistency between displayed pedestrian and driver behaviours evidenced in the present study; focusing on different road user roles in detail was shown to be important especially for planning intervention programs for specific traffic conditions or driver behaviours. Additionally, investigating different roles that young road users have provides the literature with additional knowledge which could be reflected in field administrations in the complex and dynamic nature of the traffic environment.
\end{abstract}

Keywords: Young road users, pedestrian behaviours, driver behaviours, aberrant road user behaviours, road safety 


\section{ÖZ}

Genç yol kullanıcıları, sürücü veya yaya olarak trafik kazalarına maruz kalma konusunda en savunmasız gruplardan birini oluşturmaktadır. Yaya ve sürücü davranışları, yol kullanıcılarının güvenliğinin önemli yordayıcılarındandır. Bu çalışmanın temel amacı, genç erkek ve kadın yol kullanıcılarının yaya davranışları ile sürücü davranışları arasındaki ilişkiyi araştırmaktır. Çalışmaya 19-28 yaş arası $(M=22.2, S D=1.77) 573$ genç yol kullanıcısı (316 erkek, 257 kadın) katılmıştır. Katılımcılar Yaya Davranışları Ölçeği (PBS), Sürücü Davranışları Ölçeği (DBQ), Olumlu Sürücü Davranışları Ölçeği (PDBS) ve demografik bilgi formundan oluşan bir anket bataryası tamamlamıştır. Çalışmanın amaçları doğrultusunda çalışmada ilk olarak yaya davranışları ölçeğinin faktör yapısı incelenmiştir. Bu aşamayı takiben, yaya ve sürücü davranışlarındaki cinsiyet farklılığı incelenmiştir. Cinsiyet farklılıkları açısından, erkekler kadınlara göre daha fazla yaya ihlalleri, yaya saldırgan ihlalleri, sürücü saldırgan ihlalleri, sürücü sıradan ihlalleri ve daha az sürücü dalgınlığı göstermiştir. Ayrıca, sapkın yaya davranışları sapkın sürücü davranışlarıyla pozitif ilişkili gösterirken, olumlu yaya davranışları sapkın sürücü davranışlarıyla negatif ilişki göstermiştir. Yaya dalgınlığı ve yaya saldırgan ihlalleri olumlu sürücü davranışlarıyla negatif ilişki gösterirken, yaya ihlalleri ve olumlu yaya davranışları olumlu sürücü davranışlarıyla pozitif ilişki göstermiştir. Genel olarak, sonuçlar daha fazla sapkın yaya davranışları gösteren genç yol kullanıcılarının aynı zamanda daha fazla sapkın sürücü davranışları gösterdiğini vurgulamaktadır. Bulgular sapkın sürücü davranışlarına karşı alınacak önlemler ile ilgili olarak da tartışılmıştır. Bu çalışmada belirtilen yaya ve sürücü davranışları arasındaki tutarlılık dikkate alındığında, farklı yol kullanıcısı rollerine ayrıntılı olarak odaklanmanın, özellikle belirli trafik koşulları veya sürücü davranışları için müdahale programlarının planlanmasında önemli olduğu gösterilmiştir. Ek olarak, genç yol kullanıcılarının sahip olduğu farklı rollerin araştırılması, alan yazına trafik ortamının karmaşı ve dinamik yapısında saha yönetimlerine yansıtılabilecek ek bilgiler sağlamaktadır.

Anahtar Kelimeler: Genç yol kullanıcıları, yaya davranışları, sürücü davranışları, sapkın yol kullanıcı davranışları, yol güvenliği 
According to statistics by the World Health Organization (WHO), each year, 1.35 million road users die as a result of road traffic injuries (WHO, 2018). These road traffic injuries are the leading cause of death among road users between the ages of five and 29 , in other words, children and young adults. Moreover, most of these deaths are seen in low- and middle-income countries, such as Turkey. These countries also constitute most of the world's population. A significant proportion of deaths due to road traffic injuries involves car occupants and pedestrians. In Turkey, driver and pedestrian deaths because of road traffic injuries respectively account for $22 \%$ and $23 \%$ of all road traffic deaths (WHO, 2018). Given that the leading cause of death for the young population is road traffic injuries (WHO, 2018), it is crucial to investigate their behaviours when they travel as pedestrians and as drivers. Considering the significance of pedestrians and drivers as road users and behaviours of road users for road safety, the present study aims to provide a more comprehensive picture of road users' behaviours. For that purpose, after the factorial structure of the Pedestrian Behaviour Scale and gender difference among behaviours of road users were tested, the relationship between pedestrian behaviours and driver behaviours, together with both aberrant and positive behaviours was examined for the first time in the literature in a sample from Turkey.

\section{Pedestrian Behaviours and Road Safety}

Pedestrians are some of the most vulnerable road users, along with cyclists and motorcyclists, as more than half of the deaths due to road traffic injuries involve these three groups of road users. Moreover, $88 \%$ of pedestrian travel takes place on unsafe roads (WHO, 2018). Pedestrian safety and pedestrian behaviours were affected by different road, traffic and human factors (Cloutier et al., 2017; Papadimitriou, 2016; WHO, 2018). For instance, in line with Şimşekoğlu (2015) and WHO (2018), lack of suitable infrastructure, especially in metropolitan areas, vehicle centred traffic system, low level in national-level policy implementation protecting pedestrians and personality and attitude factors of both pedestrians might be affecting the pedestrian safety in Turkey. To study risky and positive pedestrian behaviours with psychological factors, the Pedestrian Behaviour Scale (PBS) was developed (Granié, Pannetier, \& Guého, 2013). The scale was based on the framework that has been used to measure aberrant driver behaviours (Lawton, Parker, Manstead, \& Stradling, 1997; Reason, Manstead, Stradling, Baxter, \& Campbell, 1990), and positive driver behaviours (Özkan \& Lajunen, 2005). The PBS was used as a reliable and valid instrument for the investigation of pedestrian behavi- 
ours in different countries such as France (Granié et al., 2013), China (Qu, Zhang, Zhao, Zhang, \& Ge, 2016; Xu, Ge, Qu, Sun, \& Zhang, 2018), and Turkey (Demir, 2017; Nordfjærn \& Şimşekoğlu, 2013; Solmazer et al., 2020).

The original factor structure of the PBS consists of four factors: transgression, lapses, aggressive violations, and positive behaviours. Transgression items are associated with offences and errors. The second factor, lapses, is related to behaviours that result from a lack of attention. The third factor, aggressive violations, involves aggressive behaviours towards other road users. The final factor, positive behaviours, covers positive behaviours towards other pedestrians and drivers (Granié et al., 2013). However, differences in the factorial structure of the PBS had been found in various studies conducted in different countries, such as Serbia (Antić, Pešić, Milutinović, \& Maslać, 2016), the U.S. (Deb et al., 2017), Turkey (Y1ldırım, 2007) and France (Granié et al., 2013). For example, in France, violations and errors loaded on to a single factor called transgression (Granié et al., 2013), while in a study conducted in Turkey, items measuring errors and lapses loaded on to a single factor (Y1ldırım, 2007). Moreover, although Granié and colleagues' transgression factor was the combination of errors and violations (Granié et al., 2013), Deb et al. (2017) suggested that errors and violations should be separate factors. McIlroy et al. (2019) tested the validity of PBS across six countries. It was found that even though there were country differences in terms of item loadings, three factors; violations, lapses and aggressions, continued to be represented in all countries. However, positive behaviours showed low internal consistency.

Based on the dimensions of pedestrian behaviours mentioned above, the literature revealed that pedestrian behaviours also showed variety as a function of demographic variables, like age and gender. Age had been positively related to lapses and positive behaviours but negatively correlated with violations and errors (Antić et al., 2016). Other studies found that aberrant pedestrian behaviours, regardless of intention, decreased with age (Deb et al., 2017; Şimşekoğlu, 2015). Moreover, young male adults had been found to engage in riskier pedestrian behaviours (Herrero-Fernández, Macía-Guerrero, Silvano-Chaparro, Merino, \& Jenchura 2016). Granié et al. (2013) also found that pedestrians showed more transgressions, offences and errors before the age of 35 than after the age of 45 . After the age of 45, aberrant behaviours (transgressions, offences and errors) decreased. Between the ages of 35 and 45, positive behaviours were higher than other ages. In addition to age, gender differences had also been observed in pedestrian behaviours. Studies showed that female pedestrians engaged in more positive beha- 
viours than male pedestrians (Granié et al., 2013; Qu et al., 2016). For instance, females followed traffic rules more, as evidenced by higher temporal crossing compliance at traffic lights when compared to male pedestrians in general. On the other hand, males reported violating red light rules more than females (Tom \& Granié, 2011). Granié et al. (2013) also found that males showed more transgressions and had higher offence scores than females. Another research conducted in Serbia showed that male pedestrians displayed more errors, violations, and aggressive behaviours than female pedestrians (Antić et al., 2016). Similarly, in Turkey, Nordfjærn and Şimşekoğlu (2013) found that males reported more aggressive violations. Overall, the results of these studies indicated that young male pedestrians displayed more aberrant and risky pedestrian behaviours, including violations, errors and aggression (e.g., Antić et al., 2016; Deb et al., 2017; Granié et al., 2013; Tom \& Granié, 2011), while females exhibited more positive behaviours (e.g., Granié et al., 2013; Qu et al., 2016). It was also found that aberrant pedestrian behaviours had a strong positive relationship with each other and a negative relationship with positive pedestrian behaviours (Deb et al., 2017). Additionally, positive pedestrian behaviours were the most reported pedestrian behaviours (Deb et al., 2017; Qu et al., 2016).

Psychological predictors of pedestrian behaviours were studied by Demir (2017), and it was found that intention and willingness were related to pedestrian behaviours in Turkey. In another study, Solmazer et al. (2020) investigated the pedestrian behaviours across five countries (Estonia, Greece, Kosovo, Russia, and Turkey) and also found significant differences in the display of different types of behaviours between countries. For instance, Turkish pedestrians showed more transgression, lapses and aggressive behaviours compared to Estonian and Russian pedestrians. Moreover, Turkish pedestrians showed more positive behaviours than Kosovar pedestrians (Solmazer et al., 2020). Moreover, Deb et al. (2017) confirmed that the PBS is a reliable measure of pedestrian accident involvement and found that violations were related to higher involvement in accidents with injuries. In their study, lapses and aggressiveness were also related to the severity of injuries. Pedestrians who had not experienced a traffic accident reported higher lapses than those who had (Granié et al., 2013).

\section{Driver Behaviours and Road Safety}

Although pedestrian behaviours have a critical role in traffic safety, there seems to be a gap in the literature concerning the relationship between pedestrian behaviours and some other critical behaviours in traffic settings. One of those behaviour groups is dri- 
ver behaviours (or driving style) which has been widely studied in relation to many different variables. Driver behaviours refer to the ways that the drivers choose to drive or what they usually do while driving (Elander, West, \& French, 1993; Özkan \& Lajunen, 2011; Parker \& Stradling, 2001). Driver behaviours have widely been investigated based on a taxonomy that differentiates aberrant driver behaviours as intentional and unintentional or violations and errors, respectively (de Winter \& Dodou, 2010; Reason et al., 1990). Reason et al. (1990) investigated driver behaviours by the Driver Behaviour Questionnaire (DBQ). Errors were defined as "the failure of planned actions to achieve their intended consequences". In contrast, violations were defined as "deliberate deviations from those practices believed necessary to maintain the safe operation of a potentially hazardous system" (Reason et al., 1990, p. 1315-1316). In addition to aberrant driver behaviours, Özkan and Lajunen (2005) conceptualised positive driver behaviours as behaviours with an intention to mind other road users and general traffic systems. Driver behaviours have been studied in many countries and with different traffic-related outcomes (de Winter \& Dodou, 2010).

Specific demographic variables, such as age, gender and exposure to traffic settings are associated with different types of driver behaviours. For instance, researchers found the age of the driver to be negatively related to errors and violations (de Winter \& Dodou, 2010; Martinussen, Møller, \& Prato, 2014), while Chu, Wu, Atombo, Zhang and Özkan, (2019), in their study conducted in China, found that age was only negatively correlated with lapses. Gender was also shown to affect driver behaviour. For instance, Stephens and Fitzharris (2016) found that male drivers exhibited more violations, aggressive violations and errors compared to female drivers, whereas female drivers displayed more lapses compared to male drivers. Another essential demographic variable that influences driver behaviour is the extent to which a driver has been exposed to traffic settings. Indeed, male drivers and drivers with higher exposure to traffic (i.e. higher mileage or longer driving hours) tended to report more violations (de Winter \& Dodou, 2010; Reason et al., 1990). On the other hand, female drivers and drivers with more driving hours reported higher frequencies of errors (de Winter \& Dodou, 2010). Moreover, less experienced young drivers reported fewer positive driver behaviours (Guého, Granié, \& Abric, 2014). Just as positive and aberrant pedestrian behaviours were negatively correlated, so too were positive driver behaviours and both errors and violations (Guého et al., 2014; Özkan \& Lajunen, 2005). Additionally, self-reported 
errors and violations were positively related to the number of accidents (Cordazzo, Scialfa, Bubric, \& Ross; 2014; de Winter \& Dodou 2010), as was the case for pedestrian behaviours. In fact, after controlling for the demographic variables, violations continued to be a significant predictor of accident involvement in a study with Spanish drivers, indicating the predictive power of self-reported driver behaviours over and above the effects of culture and driving conditions (Gras et al., 2006).

Different studies have investigated driver behaviours in Turkey with different driver groups as well (e.g., Bener, Yildirim, Bolat, Özkan, \& Lajunen, 2016; Öz, Özkan, \& Lajunen, 2013; 2014; Öztürk \& Özkan, 2018; Üzümcüoğlu, Özkan, Wu, \& Zhang, 2019; Y1lmaz, Öz, \& Özkan, 2019). Some of those studies focused on drivers at a specific age group. For instance, Öztürk and Özkan (2018) studied the relationships between self-reported driver behaviours and simulated driver behaviours among young drivers. It was found that speeding was positively related to violations. Üzümcüoğlu and Özkan (2019) reported that young male drivers in Turkey showed more positive driver behaviours, higher mean speed and speeding deviations in a driving simulator compared to young female drivers. Moreover, Üzümcüoğlu et al. (2019) found that in Turkey, age and being male were positively associated with violations.

\section{The Relationship between Pedestrian Behaviours and Driver Behaviours}

Şimşekoğlu (2015) discussed that even though pedestrian behaviours and driver behaviours had similar phrasing, these behaviours should be considered as two different constructs. A few studies have examined the relationship between pedestrian and driver behaviours. For example, Granié et al. (2013) reported that pedestrians without a driving license engaged in more positive pedestrian behaviours. In another study, Şimşekoğlu (2015) investigated the relationship between pedestrian behaviours and driver behaviours with a sample of 289 road users, including 139 with a driving license. Among those with a driving license, pedestrian violations were positively correlated with both driver violations and driver errors/lapses. Another study, which was conducted in China (Xu, Liu, Qu, Ge, Sun, \& Zhang, 2018), found that as pedestrians, non-drivers show more transgression and aggressive behaviours than drivers. Unlike $\mathrm{Xu}$ et al. (2018a), however, Taubman-Ben-Ari and Shay (2012) found that individuals with a driving license reported more risky pedestrian behaviours, such as crossing at a red light. Moreover, it was found risky driver behaviours to be positively related to risky pedestrian behaviours. In other words, drivers with dangerous driving styles also showed more dangerous pedestrian behaviours. 
Considering the proportions of pedestrian and driver deaths due to road traffic injuries (WHO, 2018), and the impact of pedestrian behaviours (Granié et al., 2013) and driver behaviours (de Winter \& Dodou, 2010) on road safety, it is important to understand road users' behaviours as a function of their role in the traffic context. Although studies have investigated the relationship between pedestrian and driver behaviours (i.e. Şimşekoğlu, 2015), to the authors' best knowledge, the current study is the first to investigate the relationship between self-reported pedestrian behaviours and driver behaviours (including both positive pedestrian and driver behaviours) within the same group of road users who actively both walk and drive. It is believed that examining the pedestrian behaviours and driver behaviours of the same road users will contribute to an understanding of the behaviour styles of road users and provide the literature with a more compressive approach to road safety. In addition, the present study focuses specifically on young road users. As discussed earlier, young road users are one of the most vulnerable road user groups (WHO, 2018). Due to the fact that young drivers are considered to be a risk group for traffic safety, investigating the relationship between driver and pedestrian behaviours of this group will form the basis for more effective intervention programs in the future.

With respect to these, three objectives are examined in the present study. First, considering the factorial structure differences of the PBS across different countries mentioned above, and insufficiency of well-established factor structure solutions for any Turkish sample, first, the factor structure of the pedestrian behaviour questionnaire for the present sample is explored. In light of the effects of age on the behaviours of road users, exploratory factor analysis was performed to obtain a relatively stable and robust factor structure with a young road users sample from Turkey. Based on the factor structure obtained, one of the main objectives of the current study is to examine pedestrian behaviours and driver behaviours in young male and female road users. While doing so, this study aimed to investigate gender differences in those two critical road user behaviours. Following the second objective, the relationship between pedestrian and driver behaviours is investigated. With this aim, the present study has been the first one to investigate the association of both pedestrian and driver behaviours, including positive behaviours. Based on the mentioned aims of the study, the following hypotheses were formed and tested:

H1: Males will exhibit higher frequencies of aggressive and ordinary violations as drivers and pedestrians compared to females. 
H2: Aberrant pedestrian behaviours will be positively associated with aberrant driver behaviours and negatively with positive driver behaviours.

H3: Positive pedestrian behaviours will be positively associated with positive driver behaviours and negatively related to aberrant driver behaviours.

\section{METHOD}

\section{Participants}

A total of 573 young road users, who both walk and drive regularly, participated in the current study. The mean age was $22.20(S D=1.77$, Min. $=19$, Max. $=28) .55 .1 \%$ of the participants were male $(N=316)$, and $44.9 \%$ of the participants were female $(N=$ 257). Participants' average daily walk was found to be 44.84 minutes $(S D=27.09)$ long, while their average lifetime kilometres driven was $17568.96(S D=33992.91)$.

\section{Measures}

Pedestrian Behaviour Scale. The Pedestrian Behaviour Scale (PBS) was used to measure pedestrian behaviours (Granié et al., 2013). The original scale included 20 items. The original factors were transgression, lapses, aggressive behaviours, and positive behaviours. The PBS was found to be a reliable and valid measurement for the pedestrian behaviours across different ages and countries (Antić et al., 2016; Granié et al., 2013). Nordfjærn and Şimşekoğlu (2013) adapted the scale into Turkish without the positive behaviours dimension on a 5 -point Likert-type scale from $1=$ Never to $5=$ Very often. Ten items that represented pedestrian behaviours in Turkey were also included in the scale. The positive behaviours were translated into Turkish in the current study, and items representative of the original factor structure were used. In the study of Granie et al. (2013), the Cronbach's alpha internal consistency coefficients for the factors of the PBS were as follows: .89 for transgression, .83 for lapses, .70 for aggressive violations, and .53 for positive pedestrian behaviours.

Driver Behaviour Questionnaire. Driving behaviours were assessed using the Driver Behaviour Questionnaire (DBQ), which comprises 28 items on a 6-point Likert-type scale ranging from $0=$ Never to $5=$ Always. These items represented the four dimensions of driving behaviour, namely aggressive violations, ordinary violations, errors, and lapses (Lawton et al., 1997; Reason et al., 1990). The Turkish adaptation of the scale was conducted by Sümer, Lajunen, \& Özkan (2002). de Winter and Dodou (2010) also 
found that the DBQ is a reliable and valid measurement of driver behaviours and predicted road traffic accidents. In the current study, aggressive violations were assessed via three items, ordinary violations via eight items, errors via eight items, and lapses via eight items. The Cronbach's alpha reliabilities of the scale were found to be .77 for driver lapses, .80 for driver errors, .71 for aggressive driver violations and .83 for ordinary driver violations.

Positive Driver Behaviours Scale. Özkan and Lajunen (2005) developed a Positive Driver Behaviours Scale (PDBS) that focuses on helpful and polite behaviours of drivers towards other road users. The scale comprises 14 items on a 6-point Likert-type scale, all of which were used in the current study. The PDBS was found to be a reliable and valid measurement in different countries (Ersan et al., 2020; Özkan \& Lajunen, 2005; Shen, Qu, Ge, Sun, \& Zhang, 2018). The Cronbach's alpha for this scale was found to be .78 .

Demographic Information Form. In the demographic information form, participants answered questions regarding their age, gender and driver- and pedestrian-related history, such as their degree of exposure to traffic settings.

\section{Procedure}

After getting ethical approval (Protocol No: 2017-SOS-082, Date: 05.05.2017) from the Applied Ethics Research Center of Middle East Technical University, the questionnaire was distributed via social media channels and was administered through Qualtrics, an online survey platform. Snowball sampling, which is a non-probability sampling method, was used to reach participants. A total of 740 participants opened the survey link. The participants with partial responses $(N=128)$ and with outlier scores (with Z-scores over 3.5) on daily walk or lifetime kilometres $(N=39)$ were excluded from the further analysis. All participants completed the surveys, which took approximately fifteen minutes. The final data set included 573 participants.

\section{Data Analysis}

It was assumed that the combined items of Granié et al. (2013) and Nordfjærn and Şimşekoğlu (2013) might show some differences, so the factor structure of the PBS was first examined using exploratory factor analysis. While Tabachnick and Fidell (2013) recommend a cut-off point of .32 as a good rule of thumb to include items to the factors they are being loaded; in the current study a more conservative perspective was used 
and .50 was determined as the cut-off point. Moreover, the preliminary analysis showed that skewness or kurtosis values were acceptable in terms of the study variables. After four-factor structure and calculating mean values for the dimensions were decided, two-tailed parametric (Pearson's $r$ ) correlations between all study variables were obtained. For testing the $H 1$, ANCOVA analyses were conducted for pedestrian and driver behaviours. Approaching $\mathrm{H}_{2}$ and $\mathrm{H} 3$, hierarchical regression analyses were conducted to test how pedestrian behaviours related to driver behaviours after controlling for the effects of demographic variables. The VIF values for pedestrian behaviours were between one and two, indicating that multicollinearity was not a problem. Statistical analysis was conducted using SPSS v24.

\section{RESULTS}

\section{Exploratory Factor Analysis of the Pedestrian Behaviour Scale}

To examine the factor structure of the Turkish version of the PBS, principal component analysis with Promax rotation and Kaiser normalization was conducted. The Kaiser-Meyer-Olkin measure of sampling adequacy was found to be .88 . Bartlett's test of sphericity was also significant $(d f=465, p<.001)$, indicating that the data was appropriate for factor analysis. The scree-plot results supported the original four-factor structure. As a result, the analysis revealed a four-factor solution which explained $44.2 \%$ of the variance. The distribution of the items to the factors was similar to the original factor solutions. Based on this similarity in the content of the factors, it is preferred to be consistent with the original factor structure, and the factor names were held constant. A total of nine items were removed because of cross-loadings or factor loadings below the .50 cut off (See Table 1). 


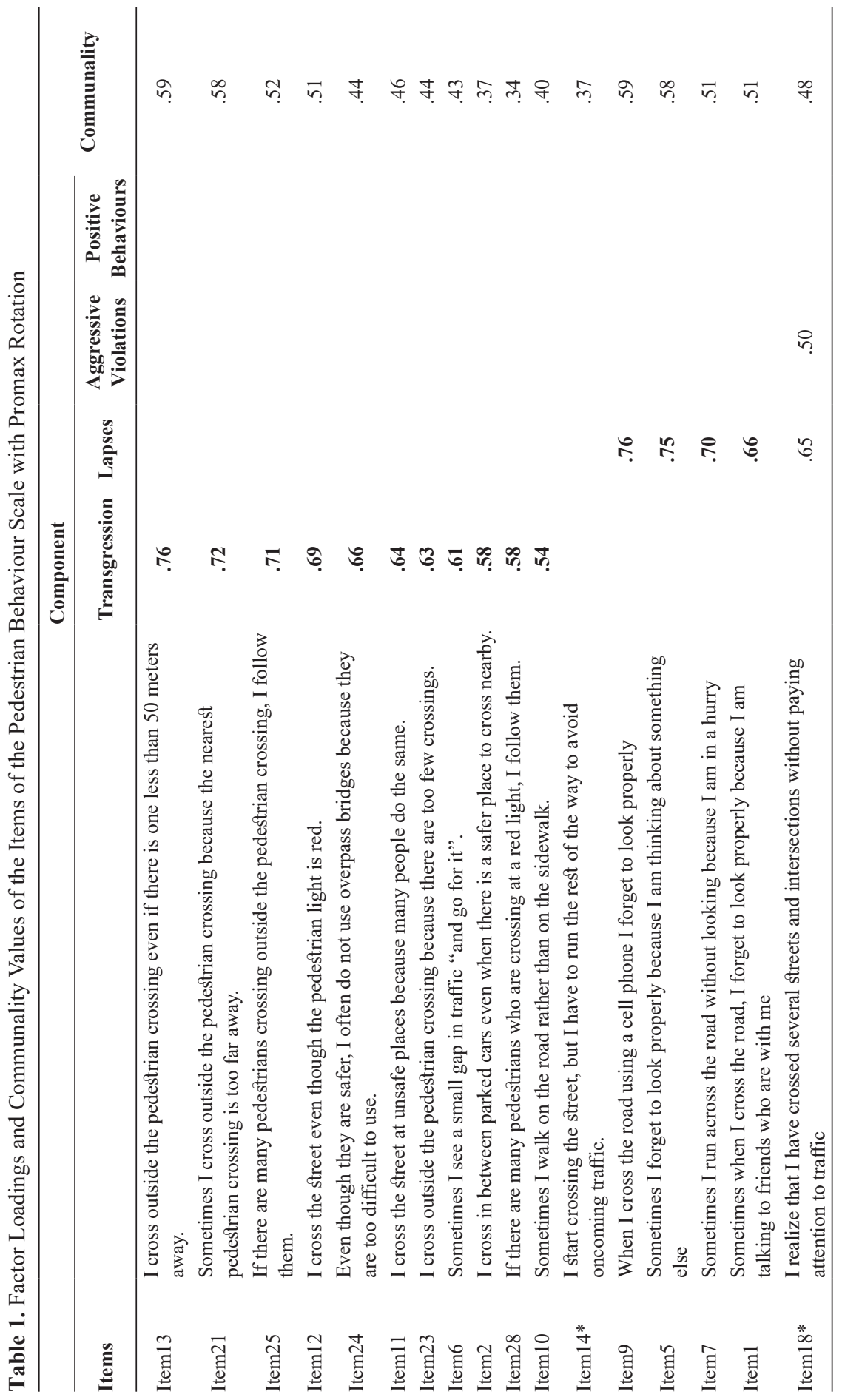




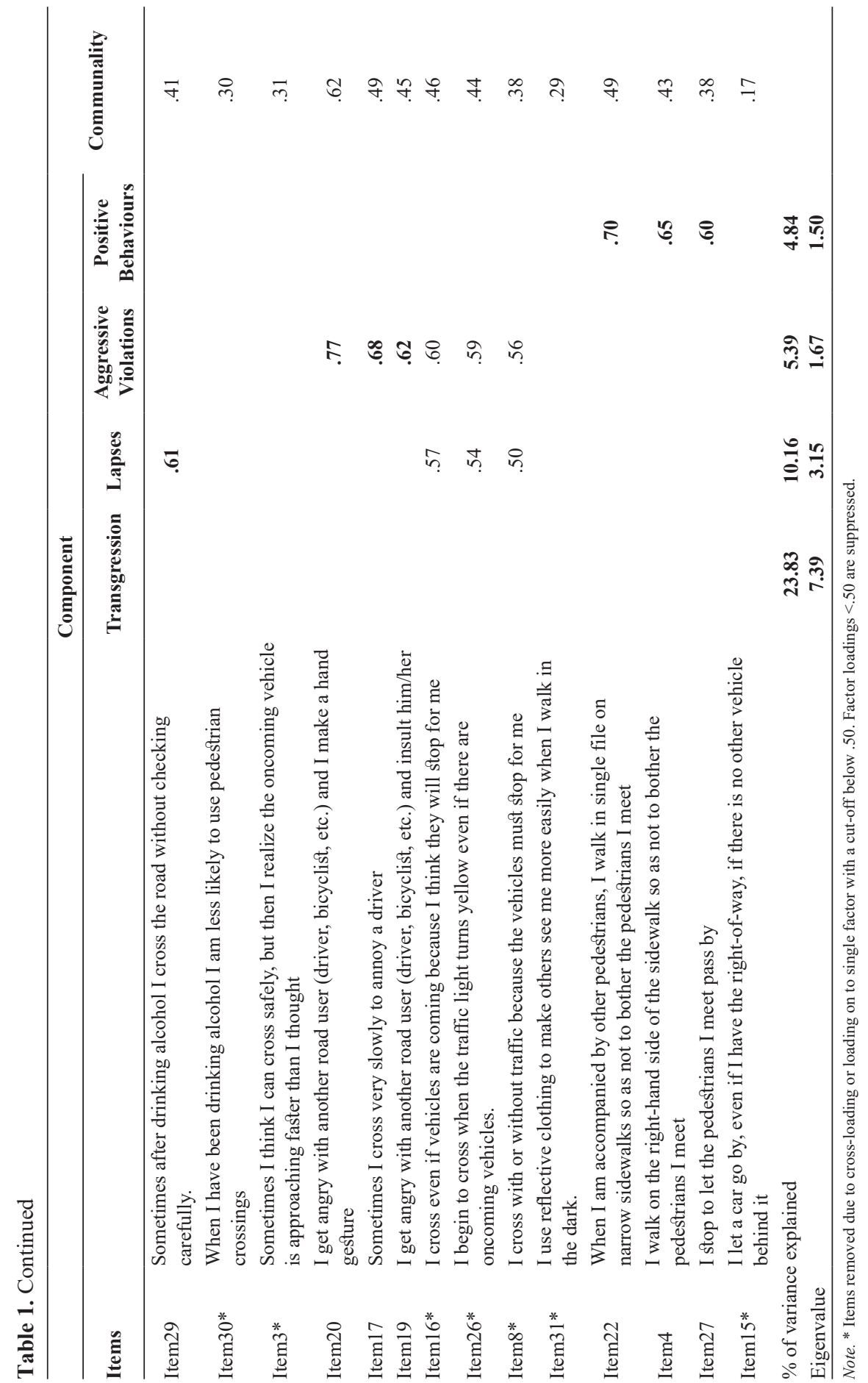


The first factor, transgression, consisted of 11 items. The communality scores of the items ranged from .34 to .59. The Cronbach's alpha reliability for transgression was found to be .87 . The transgression factor reflects intentional violations of formal and informal rules as evidenced by ordinary violations or errors while walking.

The second factor, lapses, consists of five items. The communality scores of the items ranged from .41 to .59. The Cronbach's alpha reliability for lapses was found to be .78. Lapses refer to behaviours exhibited while walking that result from memory failures and not being careful.

The third factor, aggressive violations, consists of three items. The communality scores of the items ranged from .45 to .62 . The Cronbach's alpha reliability for aggressive violations was found to be .67 . The third factor corresponds to behaviours involving anger or aggressive behaviours.

The fourth and final factor, positive behaviours, consists of three items. The communality scores of the items ranged from .38 to .49 . The Cronbach's alpha reliability for positive behaviours was found to be .56. Positive behaviours reflect pedestrians' protective behaviours towards other pedestrians.

\section{Correlations}

The correlations between the study variables were all analysed using bivariate correlations (See Table 2.). Age was significantly positively correlated with both annual $(r(513)=.12, p<.01)$, and lifetime kilometres $(r(527)=.25, p<.001)$ driven, and positive behaviours while walking $(r(571)=.11, p \leq .010)$, but was significantly negatively correlated with daily walking time $(r(564)=-.20, p<.001)$ and lapses while driving $(r(571)=-.11, p<.01)$ and walking $(r(571)=-.08, p<.05)$. A significant negative correlation was also observed between daily walking time and lifetime kilometres driven $(r(521)=-.13, p<.01)$, aggressive violations $(r(564)=-.11, p<.05)$ and ordinary violations $(r(564)=-.18, p<.001)$ while driving. Annual kilometres driven was significantly positively associated with lifetime kilometres driven $(r(507)=.80, p<.001)$ and ordinary violations while driving $(r(513)=.12, p<.01)$. Similarly, lifetime kilometres driven was also significantly positively correlated with ordinary violations while driving $(r(527)=.21, p<.001)$ and aggressive violations while driving $(r(527)=.11, p<.01)$ and walking $(r(527)=.11, p<.05)$. 
Aberrant behaviours while driving (lapses, errors, and aggressive and ordinary violations) and walking (transgression, lapses and aggressive violations) were positively associated with each other. Positive behaviours while driving were significantly negatively correlated with errors while driving $(r(571)=-.29, p<.001)$, aggressive violations while walking $(r(571)=-.16, p<.001)$, and lapses while driving $(r(571)=-.28, p<.001)$ and walking $(r(571)=-.27, p<.001)$. Finally, positive behaviours while walking were significantly positively correlated with positive behaviours while driving $(r(571)=.56$, $p<.001)$, and negatively related to lapses $(r(571)=-.23, p<.001)$, errors $(r(571)=-.24$, $p<.001)$, and aggressive $(r(571)=-.09, p<.05)$ and ordinary $(r(571)=-.17, p<.001)$ violations while driving, and lapses $(r(571)=-.25, p<.001)$ and aggressive violations $(r(571)=-.14, p<.001)$ while walking. 


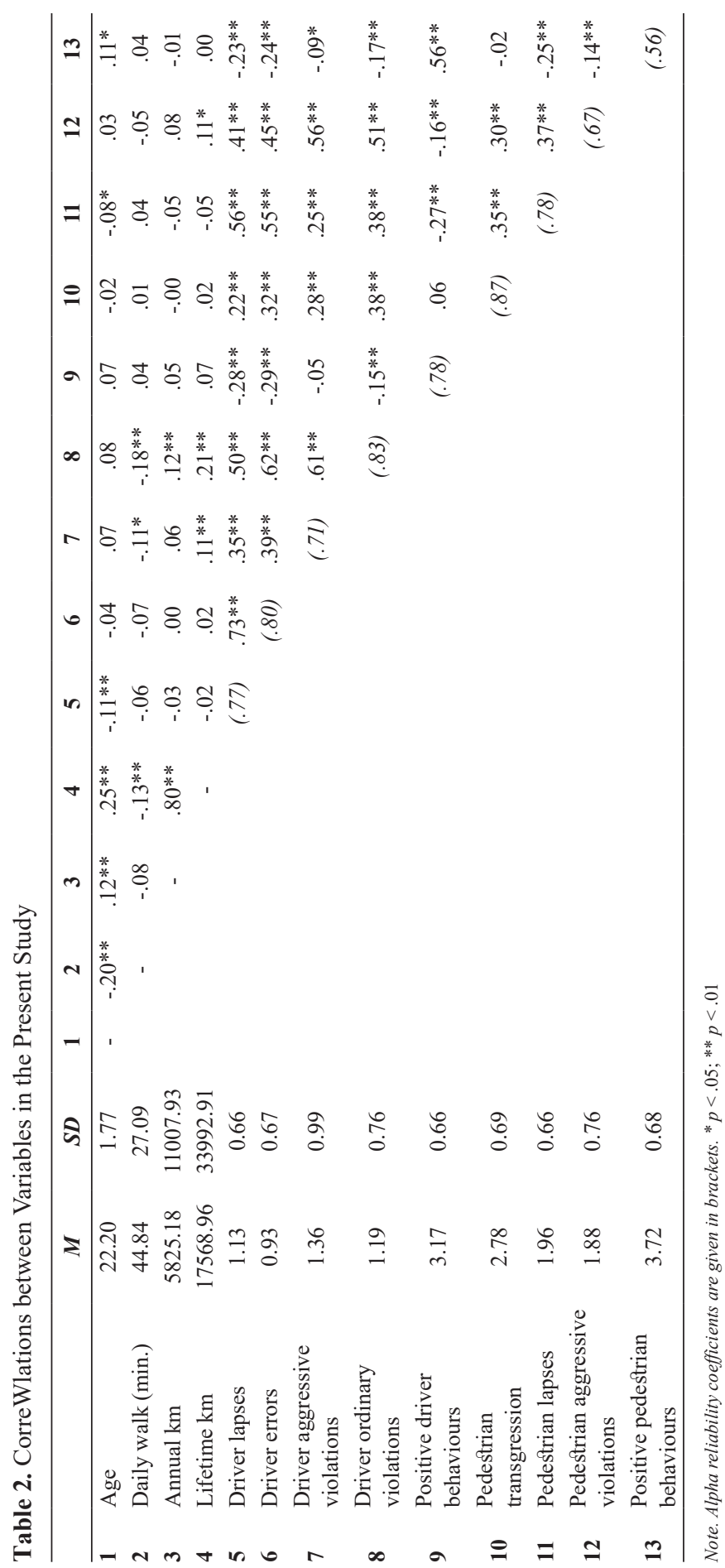




\section{Gender Differences among Pedestrian Behaviours and Driver Behaviours}

To investigate gender differences in pedestrian behaviours and driver behaviours, eight ANCOVA analyses were conducted with age as a covariate (See Table 3.). For driver behaviours, male drivers showed more aggressive violations $\left(\eta_{p}^{2}=.02\right)$ and ordinary violations $\left(\eta_{p}^{2}=.05\right)$ and fewer lapses $\left(\eta_{p}^{2}=.01\right)$ than female drivers. In terms of pedestrian behaviours, male pedestrians reported more transgressions $\left(\eta_{p}^{2}=.03\right)$ and aggressive violations $\left(\eta_{\mathrm{p}}^{2}=.02\right)$ while walking than female pedestrians. Overall, the results fully support $H 1$, as males showed more pedestrian transgressions, pedestrian aggressive violations, driver aggressive violations, driver ordinary violations and fewer driver lapses than females. However, the effect sizes were rather small, except for that of driver ordinary violations, which had a medium effect size. No gender differences were found in driver errors and positive behaviours, and in pedestrian lapses and positive behaviours.

Table 3. Gender Difference between Variables in the Present Study

\begin{tabular}{|c|c|c|c|c|c|c|}
\hline \multirow{2}{*}{ Variables } & \multicolumn{2}{|c|}{ Female } & \multicolumn{2}{|c|}{ Male } & \multirow[t]{2}{*}{$F(\mathbf{1}, \mathbf{5 7 0})$} & \multirow[t]{2}{*}{$p$} \\
\hline & $M$ & $S D$ & $M$ & $S D$ & & \\
\hline \multicolumn{7}{|l|}{ Driver Behaviours } \\
\hline Lapses & 1.20 & .60 & 1.08 & .70 & 3.71 & .054 \\
\hline Errors & .90 & .63 & .95 & .70 & 1.25 & .264 \\
\hline Aggressive Violations & 1.19 & .89 & 1.51 & 1.04 & 12.85 & .000 \\
\hline Ordinary Violations & 1.00 & .69 & 1.35 & .78 & 28.96 & .000 \\
\hline Positive Behaviours & 3.12 & .63 & 3.21 & .68 & 1.95 & .163 \\
\hline \multicolumn{7}{|l|}{ Pedestrian Behaviours } \\
\hline Transgression & 2.65 & .67 & 2.88 & .69 & 16.19 & .000 \\
\hline Lapses & 1.99 & .68 & 1.94 & .65 & .36 & .546 \\
\hline Aggressive Violations & 1.76 & .70 & 1.99 & .79 & 13.00 & .000 \\
\hline Positive Behaviours & 3.71 & .64 & 3.74 & .71 & .22 & .882 \\
\hline
\end{tabular}

\section{The Relationship between Pedestrian Behaviours and Driver Behaviours}

In order to test the $H 2$ and $H 3$, five multiple hierarchical regression analyses were conducted to determine the ability of pedestrian behaviours to predict driver behaviours. Demographic variables (i.e. age, gender, and lifetime kilometres driven) were entered into the model in the first step to control the statistical effects. In the second step, all types of pedestrian behaviours were entered into the model as independent variables. This analysis was repeated for driver behaviours as lapses, errors, aggressive violations, ordinary violations, and positive driver behaviours separately (See Table 4.). Before the regression analysis, the mean differences between the same forms of pedestrian behaviours 
and driver behaviours were tested by using paired-samples $t$-test. The differences between the means of pedestrian and driver lapses $(t(572)=-32.14, p<.001)$, transgression and driver errors $(t(572)=-55.84, p<.001)$, transgression and driver ordinary violations $(t(572)=-46.74, p<.001)$, pedestrian and driver aggressive violations $(t(572)=$ $-14.68, p<.001)$ and pedestrian and driver positive behaviours $(t(572)=-21.14, p<$ .001 ) were all significant, indicating the same form of pedestrian and driver behaviours were not similar and did not create a limitation for the regression analyses. 


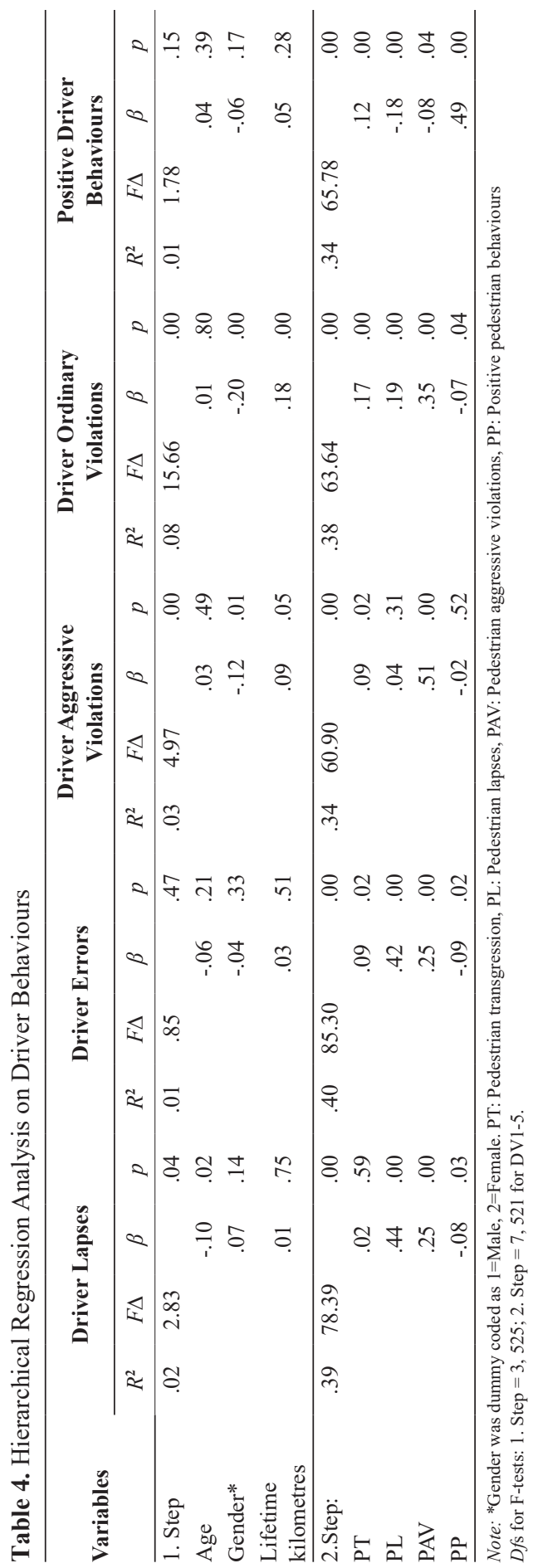


For driver lapses, the model was significant $(F(7,521)=46.72, p<.001)$. Pedestrian lapses $(95 \% \mathrm{CI}[.36, .52])$ and pedestrian aggressive violations $(95 \% \mathrm{CI}[.15, .28])$ were positively related to driver lapses, while age (95\% CI [-.07, -.00]) and positive pedestrian behaviours (95\% CI [-.14, -.01]) were negatively related to driver lapses. In other words, as pedestrian lapses and aggressive violations increased, driver lapses also increased, but as age and positive pedestrian behaviours increased, a decrease in driver lapses was observed.

For driver errors, the model was significant $(F(7,521)=49.34, p<.001)$. Pedestrian transgressions $(95 \%$ CI $[.02, .16])$, pedestrian lapses (95\% CI $[.35, .51])$, and pedestrian aggressive violations $(95 \%$ CI $[.16, .29])$ were positively related to driver errors, while positive pedestrian behaviours $(95 \%$ CI $[-.16,-.02])$ were negatively related to driver errors. In other words, higher frequencies of driver errors were associated with more aberrant pedestrian behaviours and less positive pedestrian behaviours.

For driver aggressive violations, the model was significant $(F(7,521)=37.90, p<$ $.001)$. Lifetime kilometres driven $(95 \%$ CI $[.00, .00])$, pedestrian transgressions $(95 \%$ CI $[.02, .24])$ and pedestrian aggressive violations (95\% CI $[.57, .77])$ were positively related to driver aggressive violations, while gender (95\% CI [-.40, -.06]) was negatively related to driver aggressive violations. Male drivers, drivers with higher lifetime kilometres and drivers with more pedestrian transgressions and aggressive violations showed more aggressive violations while driving.

For driver ordinary violations, the model was significant $(F(7,521)=46.27, p<$ $.001)$. Lifetime kilometres driven $(95 \%$ CI $[.00, .00])$, pedestrian transgressions $(95 \%$ CI $[.10, .27])$, pedestrian lapses $(95 \%$ CI $[.13, .31])$, and pedestrian aggressive violations $(95 \%$ CI $[.28, .43])$ were positively related to driver ordinary violations, while gen$\operatorname{der}(95 \%$ CI $[-.43,-.17])$ and positive pedestrian behaviours (95\% CI [-.16, -.00]) were negatively related to driver ordinary violations. Thus, as lifetime kilometre and aberrant pedestrian behaviours increased, driver ordinary violations increased. Moreover, female drivers and drivers reporting more positive pedestrian behaviours showed less violations while driving.

For positive driver behaviours, the model was significant $(F(7,521)=38.72, p<$ $.001)$. Pedestrian transgression $(95 \%$ CI $[.04, .18])$ and positive pedestrian behaviours $(95 \%$ CI $[.40, .54])$ were positively related to positive driver behaviours, while pedestri- 
an lapses (95\% CI [-.26, -.10]) and pedestrian aggressive violations (95\% CI [-.14, $-.00]$ ) were negatively related to positive driver behaviours. In other words, drivers who showed more transgression and positive pedestrian behaviours also showed higher positive behaviours while driving, while those with more lapses and aggressive violations while walking also showed fewer positive behaviours while driving.

Overall, the results showed that pedestrian behaviours contribute significantly, at least $30 \%$, to the models that predict driver behaviours after controlling for age, gender and lifetime kilometres driven. However, only partial support for $H 2$ and $H 3$ was obtained. For $H 2$, higher frequencies of aberrant pedestrian behaviours were related to higher frequencies of aberrant driver behaviours, although pedestrian transgressions and pedestrian lapses did not emerge as significant predictors of driver lapses and driver aggressive violations, respectively. Moreover, a higher frequency of pedestrian lapses and aggressive violations were negatively associated with positive driver behaviours. However, pedestrian transgressions were positively associated with positive driver behaviours. For the $H 3$, positive pedestrian behaviours were indeed positively associated with positive driver behaviours and negatively related to aberrant driver behaviours. However, contrary to expectations, positive pedestrian behaviours did not significantly predict driver aggressive violations. The standardised beta coefficients showed that pedestrian lapses were the strongest predictor for driver lapses and errors, pedestrian aggressive violations were the strongest predictor for the driver aggressive and ordinary violations, and positive pedestrian behaviours were the strongest predictor of positive driver behaviours.

\section{DISCUSSION}

As highlighted by WHO (2018), road traffic accidents are the leading cause of death among young road users. The aim of the present study was to investigate the relationship between pedestrian behaviours and driver behaviours of young male and female road users. To do this, first, the factor structure of the PBS was tested for the first time in the literature in a sample from Turkey. The factorial structure replicated the original factorial structure (Granié et al., 2013) by representing the four factors, namely; lapses, transgression, aggressive violations and positive behaviours. Contrary to the previous studies conducted in Turkey (Nordfjærn \& Şimşekoğlu, 2013; Yıldırım, 2007), suppressing and excluding item loadings below .50 resulted in better differentiation between the 
dimensions of pedestrian behaviours and produced a more conservative and relatively shorter scale. Moreover, all subscales, except for positive pedestrian behaviours, also showed good internal reliability (Granié et al., 2013). In line with the previous findings (Antić et al., 2016; Granié et al., 2013), the transgression factor consisted of both violation and error items. Even though the PBS was found to differentiate errors and violations (Deb et al., 2017), the mentioned differentiation may not have the same logic in the error and violation differentiation of driver behaviours (de Winter \& Dodou, 2010). For this reason, the combined use of violations and errors is also advised in Turkey. As mentioned by Granié et al. (2013), not following legal rules (violations) and rules of caution (errors) may be regarded as the same type of behaviour with similar consequences. They can also be differentiated from lapses, given the intentional nature of not following these formal or informal rules. Similar to the findings of McIlroy et al. (2019), positive behaviours showed relatively low internal consistency compared to other subscales.

The correlations showed that among young road users, age was positively associated with positive behaviours while walking, and negatively related to lapses while driving and walking. Furthermore, both pedestrian and driver lapses decreased with age, which is in line with previous research on pedestrian (Deb et al., 2017) and driver (Chu et al., 2019) lapses. Moreover, drivers with higher lifetime kilometres reported more driver violations, which supports the previous findings (de Winter \& Dodou, 2010; Reason et al., 1990). Additionally, in the current study, the daily duration of walking was not associated with any type of pedestrian behaviour. This finding is contrary to that of Antic et al. (2016), who found that distance walked daily was positively associated with errors and positive behaviours. Similar to the findings of Guého et al. (2014) and Özkan and Lajunen (2005) for driver behaviours, in the current study, aberrant behaviours as a driver or a pedestrian were positively associated with each other, and negatively associated with positive behaviours while driving and walking, except for the correlations between aggressive violations-positive behaviours while driving and transgression-positive behaviours while walking.

As discussed in many studies, male and female road users show differences in both pedestrian behaviours (Antić et al., 2016; Granié et al., 2013) and driver behaviours (de Winter \& Dodou, 2010; Stephens \& Fitzharris, 2016). Such gender differences were also found in the present study as well. More specifically, in support of $H 1$, male drivers showed more aggressive and ordinary violations, and fewer lapses than females, in kee- 
ping with previous findings (de Winter \& Dodou, 2010; Stephens \& Fitzharris, 2016). In terms of the pedestrian behaviours, males showed more transgressions and aggressive violations than females, a result which has also been documented in previous studies (Antić et al., 2016; Granié et al., 2013; Tom \& Granié, 2011). Additionally, as Antić et al. (2016) found, pedestrian lapses and positive behaviours were not significantly different in males and females. It can be concluded that males violate traffic rules as either pedestrians or drivers more than females, and, as predicted, commit more violations than females.

Regarding the $H 2$ and $H 3$, the regression results showed that pedestrian behaviours are important predictors of driver behaviours and partially supported these hypotheses. Greater frequencies of aberrant pedestrian behaviours were associated with greater frequencies of aberrant driver behaviours. The only exceptions for this relation are pedestrian transgressions, which did not predict driver lapses, and pedestrian lapses, which did not predict driver aggressive violations. Moreover, aberrant pedestrian behaviours were negatively associated with positive driver behaviours, except for pedestrian transgressions, which was found to be positively associated with positive driver behaviours. On the other hand, positive pedestrian behaviours were positively related to positive driver behaviours and negatively related to all aspects of aberrant driver behaviours, except for aggressive violations. Moreover, among the dimensions of pedestrian behaviours, aggressive violations, and positive pedestrian behaviours show a clear pattern. Specifically, pedestrian aggressive violations were positively associated with all aberrant driver behaviours and negatively associated with positive driver behaviours. In line with the previous findings of Taubman-Ben-Ari and Shay (2012) and Şimşekoğlu (2015), these results indicate that aberrant pedestrian behaviours and aberrant driver behaviours go hand in hand. Risky behaviours might reflect a general tendency that does not depend on whether the road user travels as a pedestrian or a driver. Positive behaviours also show the same pattern. In other words, road users who show positive pedestrian behaviours continue to show positive driver behaviours as well.

These results are especially important in that they shed light on the relationship between the pedestrian behaviours and driver behaviours of the same group of road users. Overall, individuals reported showing similar risky or positive behaviours as pedestrians and as drivers. Another important finding that needs further attention is the positive relationship between pedestrian transgressions and both positive driver behavi- 
ours and aberrant driver behaviours, except for lapses. These results might be discussed with respect to the item content of the pedestrian transgression statements. Even though items like "I cross outside the pedestrian crossing even if there is one less than 50 meters away." and "I cross outside the pedestrian crossing because there are too few crossings." represent similar patterns of pedestrian behaviour, the motivation behind them might be different. For instance, the latter item might be interpreted as improper crossing behaviour, that might be the result of a lack of infrastructure. This might indicate that a certain group of pedestrians makes these violations because of infrastructure problems, so this group might also be showing positive driver behaviours.

In light of the results of the present study, it should be stressed that the road users are consistently displaying positive or aberrant behaviours regardless of whether they are drivers or pedestrians. That is, if a road user displays a positive or aberrant behaviour in a specific road user role (e.g., as drivers), that same road user will show the same pattern of behaviour in the other road user role as well (e.g., as pedestrians). Although there are similarities between aberrant pedestrian and driver behaviours, it should also be noted that the consequences of these behaviours are different. Aggressive violations while walking are the strongest predictor of violations while driving. As a vulnerable road user, the adverse consequences of aggressive violations while walking can be different than the consequences while driving. However, as discussed by Deb et al. (2017) and de Winter and Dodou (2010), violations while driving and walking were associated with self-reported accident involvement. Aggressive behaviours while walking were associated with increased severity of injuries. Therefore, considering both pedestrian and driver violations is essential while planning road safety interventions.

Countermeasure programs that target aberrant driver behaviours should also focus on pedestrian behaviours. Özkan and Lajunen (2011) stated that the traffic system is a dynamic and complex system requiring continuous interaction with different road users and different agents who are active all the time. Cloutier et al. (2017) highlighted the importance of interactions between pedestrians and drivers while crossing roads. For a safer traffic environment, it is important to understand interactions within the system and intervene behaviours of road users accordingly. Countermeasure programs that aim to change the behaviours of different road user groups might be more effective than the ones that focus on just one group. For example, rather than implementing education programs for drivers' rule violations, education programs focusing on various road 
users' rule violations may result in more successful behavioural change. These findings may also be used to educate children. Teaching children safe behaviours that are the characteristics of different road users may help them in their present and future road user roles. The findings of the current study, even though not experimental, suggest that teaching child safe pedestrian behaviours could help them to be safe drivers in the future. These dynamic programs might also provide a better understanding of the relationship between pedestrian behaviours and driver behaviours.

As discussed by Solmazer et al. (2020), problematic pedestrian behaviours could show differences among countries. However, for Turkey, it was stated that all different forms of aberrant pedestrian behaviours should be taken into account while conducting evaluation and monitoring and developing intervention programs (Solmazer et al., 2020). Similarly, the results of the present study also showed aberrant pedestrian behaviours were positively associated with aberrant driver behaviours. It can be claimed that traffic authorities should take a holistic approach for road safety considering the different roles of road users. Moreover, rehabilitation activities should consider these consistencies of aberrant road user behaviours. One of the other important implications of the present findings is for the policymakers. In Turkey, 2019 was announced as the Pedestrian Priority Year in which the various media campaigns and policies were implemented. The results of the current study demonstrated that pedestrian behaviours and driver behaviours go hand in hand. It can be claimed that adopting a more comprehensive policy might be more effective. Given that violating pedestrians are also violating drivers, putting a group of road users as a priority group for road safety may not be as effective as expected in the long run. Even though prioritising pedestrians in traffic requires the design and implementation of certain rules for a safe traffic system, violating road users may still continue to violate the rules either as pedestrians or drivers. Future countermeasures should also consider these consistent behaviours. In other words, based on the findings of the current study, countermeasures such as education programs or advertisements may be more effective if the focus is on behaviours of road users while driving, walking or cycling. For instance, public training may take place by highlighting the different forms of violations of both pedestrians and drivers. Enforcement can also be applied for aberrant behaviours (e.g. passing a red light while walking or driving) of all road user groups.

Different factors such as individual values or demographic variables (Solmazer et al., 2020), traffic safety and risk perception (Dinh, Vũ, McIlroy, Plant, \& Stanton, 
2020a) and fatalistic beliefs (Dinh, Vu, McIlroy, Plant, \& Stanton, 2020b) could be affecting the pedestrian behaviours. Similar to pedestrian behaviours, demographic variables such as age, gender, and exposure (de Winter \& Dodou, 2010), risk perception (Ulleberg \& Rundmo, 2003) and fatalistic beliefs (Şimşekoğlu et al., 2013) also associated with driver behaviours. From this point of view, the present study presents some correlational relations between pedestrian behaviours and driver behaviours. The results could be interpreted as showing a similar pattern of behaviours of road users regardless of being a driver or a passenger. These antecedent factors could be playing an important role in the behaviours of road users. The findings of the current study are the first in this bilateral relationship. In this context, future studies investigating the effects of antecedent factors will result in more comprehensive findings for road safety.

One of the other important implications of the present study is the positive effects of positive behaviours while driving or walking. The results showed that positive behaviours while driving and walking were positively associated with each other and negatively associated with aberrant behaviours. As discussed by Özkan and Lajunen (2005), positive behaviours can be evaluated as secondary tasks and are exhibited in certain situations. In addition to focusing on the aberrant behaviours, more research on the positive pedestrian and driver behaviours is needed. It is possible that if road safety campaigns and public policies that focus on decreasing the frequencies of aberrant driver behaviours, also focus on increasing positive behaviours, the effects on safety may be stronger. With respect to the results of the current study, the authors believe that investigating the behaviours of road users in different roles can provide more comprehensive and detailed information on road safety.

Some crucial points should be specified before concluding. First of all, the present study was conducted using self-report measures with online data collection. Despite the advantages of online data collection, Lefever, Dal and Matthiasdottir (2007) highlighted the potential technical and reliability problems such as lack of willingness and problems with internet services. Even though a few studies (e.g., Deb et al., 2017; de Winter \& Dodou, 2010) have shown significant associations between self-reported behaviours and accident involvement, and self-report measures have been found to relate to real behaviours and outcomes in traffic (Bener \& Crundall, 2008; Taubman-Ben-Ari, Eherenfreund-Hager, \& Prato, 2016), common methods variance, publication bias, social desirability and validity problems are all concerns associated with the use of self-report 
measures (af Wåhlberg, Barraclough, \& Freeman, 2015; af Wåhlberg, Dorn, \& Kline, 2011). As such, participants' responses may not reflect their true pedestrian and driver behaviours. However, as found by Papadimitriou, Lasarre and Yannis (2016), self-reported pedestrian crossing behaviours were similar to observed pedestrian behaviours. Using both self-reported and observed behavioural data might be helpful to overcome this limitation. As a critical remark, it is also possible to mention the scaling differences of the DBQ and the PBS being used in the present study. The DBQ is evaluated in a 6-point Likert scale whereas the PBS is based on a 5-point Likert scale. Although the participants were well-informed about the details of scaling in the instructions of the questionnaires, and the mentioned scale difference is a very small one which is not considered as enough to affect the results in the present study; comparing two different questionnaires with differences in the scaling should be considered in order to prevent any ambiguity about the evaluation of the results. In studies to follow, this issue should be considered, and methods should be constructed accordingly. Future studies might be conducted using simulators or observations. The second issue is related to the participant group involved in the present study. As the study focuses on the behaviours of young road users, the implication of the results could be only generalised to the young road users. Future studies should investigate the same associations with other road user groups from different ages.

The present study was non-experimental, therefore the predictor-outcome relationship was constructed on a theoretical basis. The relationship between driver behaviour and pedestrian behaviour was investigated by considering pedestrian behaviour as a predictor variable of the driver behaviours. It is well known that people might have a variety of road user roles in the traffic system, with each role being learned and practised at different times of life. For instance, road users become part of the traffic system as individual drivers after a certain age and by meeting certain conditions. However, before this age, they take the roles of being pedestrians and/or passengers in the traffic system. In this process, they have the chance of observing, learning and influencing the traffic system based on the roles they take. Supporting this argument, Scott-Parker, Watson, King, and Hyde (2014) highlighted the importance of behaviours of family and friends over young novice drivers. The researchers indicated that risky friends were associated with risky behaviours of young drivers. Moreover, on-the-road behaviours of daughters were affected negatively from the risky behaviours of mothers, and on-the- 
road behaviours of sons were also negatively affected by the risky behaviours of fathers. Scott-Parker, Watson, King and Hyde (2015) also reported that risky young drivers tend to imitate the risky behaviours of parents. In addition to being influenced by different factors and other road users in the traffic system, people may also be influenced by their own different roles in that system as well. Especially people's previously learned roles could be related to the next coming ones. Although the present study is constructed based on this understanding and studied pedestrian and driver behaviour relationship in a young road user group, in order to understand traffic settings as a whole and in more detail, more studies with different road user groups are needed. In the future research, using longitudinal design would be beneficial to understand the influence of different factors on road user behaviours of young road users in different roles as well as the interaction between their roles and different internal and external factors.

In conclusion, the results of the current work provide a different point of view regarding young road users' pedestrian behaviours and driver behaviours. Both pedestrian behaviours (Deb et al., 2017; Granié et al., 2013) and driver behaviours (Cordazzo et al., 2014; de Winter \& Dodou, 2010) are important for the safety of road users. For the first time in the literature, the relationship between pedestrian and driver behaviours, together with both aberrant and positive behaviours was investigated using the same road user group. The results showed that pedestrian behaviours and driver behaviours are related to each other. Aberrant behaviours while driving and walking are positively related to each other, and positive pedestrian and driver behaviours are mostly negatively related to aberrant pedestrian and driver behaviours. Moreover, male road users showed more pedestrian transgressions, pedestrian aggressive violations, driver aggressive violations, driver ordinary violations and fewer driver lapses compared to female road users. Overall, aberrant and positive pedestrian and driver behaviours were highly consistent and pedestrian behaviours significantly related to driver behaviours.

Ethics Committee Approval: After getting ethical approval (Protocol No: 2017-SOS082, Date: 05.05.2017) from the Applied Ethics Research Center of Middle East Technical University, the questionnaire was distributed via social media channels and was administered through Qualtrics, an online survey platform. 
Ethics Committee Approval: After getting ethical approval (Protocol No: 2017-SOS-082, Date: 05.05.2017) from the Applied Ethics Research Center of Middle East Technical University, the questionnaire was distributed via social media channels and was administered through Qualtrics, an online survey platform

Peer-review: Externally peer-reviewed.

Author Contributions: Conceptualisation- İ.Ö., B.Ö.; Methodology- İ.Ö.; Writing/original draft- İ.Ö.; Writing/ review and editing- İ.Ö., B.Ö.

Conflict of Interest: The authors have no conflict of interest to declare.

Grant Support: The authors declared that this study has received no financial support.

Etik Komite Onayı: Orta Doğu Teknik Üniversitesi Uygulamalı Etik Araştırma Merkezi’nden etik onay (Protokol No: 2017-SOS-082, Tarih: 05.05.2017) alındıktan sonra, anket sosyal medya kanalları üzerinden dağıtılmış ve online anket platformu Qualtrics üzerinden uygulanmıştır.

Hakem Değerlendirmesi: Dış bağımsız.

Yazar Katkıları: Kavramsallaştırma- İ.Ö., B.Ö.; Metodoloji- İ.Ö.; Yazım/orijinal taslak- İ.Ö.; Yazım/değerlendirme ve düzenleme- İ.Ö., B.Ö.

Finansal Destek: Yazarlar bu çalışma için finansal destek almadığını beyan etmiştir.

\section{References}

af Wåhlberg, A. E., Barraclough, P., \& Freeman, J. (2015). The Driver Behaviour Questionnaire as accident predictor: A methodological re-meta-analysis. Journal of Safety Research, 55, 185-212. doi:10.1016/j.jsr.2015.08.003

af Wåhlberg, A. E., Dorn, L., \& Kline, T. (2011). The Manchester Driver Behaviour Questionnaire as predictor of road traffic accidents. Theoretical Issues in Ergonomics Science, 12, 66-86. doi:10.1080/14639220903023376

Antić, B., Pešić, D., Milutinović, N., \& Maslać, M. (2016). Pedestrian behaviours: Validation of the Serbian version of the pedestrian behaviour scale. Transportation Research Part F: Traffic Psychology and Behaviour, 41, 170-178. doi:10.1016/j.trf.2016.02.004

Bener, A., \& Crundall, D. (2008). Role of gender and driver behaviour in road traffic crashes. International Journal of Crashworthiness, 13(3), 331-336. doi:10.1080/13588260801942684

Bener, A., Yildirim, E., Bolat, E., Özkan, T., \& Lajunen, T. (2016). The driver behaviour questionnaire as an accident predictor in cross-cultural countries in Qatar and Turkey: Global Public Health Problem. Journal of Advances in Medicine and Medical Research, 15(7), 1-9. doi:10.9734/ BJMMR/2016/25719

Chu, W., Wu, C., Atombo, C., Zhang, H., \& Özkan, T. (2019). Traffic climate, driver behaviour, and accidents involvement in China. Accident Analysis and Prevention, 122, 119-126. doi:10.1016/j. aap.2018.09.007

Cloutier, M. S., Lachapelle, U., d'Amours-Ouellet, A. A., Bergeron, J., Lord, S., \& Torres, J. (2017). "Outta my way!" Individual and environmental correlates of interactions between pedestrians and vehicles during street crossings. Accident Analysis and Prevention, 104, 36-45. doi:10.1016/j. aap.2017.04.015

Cordazzo, S. T. D., Scialfa, C. T., Bubric, K., \& Ross, R. J. (2014). The Driver Behaviour Questionnaire: A North American analysis. Journal of Safety Research, 50, 99-107. doi:10.1016/j.jsr.2014.05.002 de Winter, J.C.F., \& Dodou, D. (2010). The Driver Behaviour Questionnaire as a predictor of accidents: A meta-analysis. Journal of Safety Research, 41, 463-470. doi:10.1016/j.jsr.2010.10.007 
Deb. S., Strawderman, L., DuBien, J., Smith, B., Carruth, D. W., \& Garrison, T. M. (2017). Evaluating pedestrian behavior at crosswalks: Validation of a pedestrian behavior questionnaire for the U.S. population. Accident Analysis and Prevention, 106, 191-201. doi:10.1016/j.aap.2017.05.020

Demir, B. (2017). The Social psychological predictors of pedestrian behaviors. (Unpublished Doctoral Dissertation). Middle East Technical University, Ankara, Turkey.

Dinh, D. D., Vũ, N. H., McIlroy, R. C., Plant, K. A., \& Stanton, N. A. (2020a). Effect of attitudes towards traffic safety and risk perceptions on pedestrian behaviours in Vietnam. IATSS Research, 44, 238-247. doi:10.1016/j.iatssr.2020.01.002

Dinh, D. D., Vu, N. H., Mcllroy, R. C., Plant, K. A., \& Stanton, N. A. (2020b). Examining the roles of multidimensional fatalism on traffic safety attitudes and pedestrian behaviour. Safety Science, 124, 104587. doi:10.1016/j.ssci.2019.104587Elander, J., West, R., \& French, D. (1993). Behavioral correlates of individual differences in road-traffic crash risk: An examination method and findings. Psychological Bulletin, 113(2), 279-294. doi:10.1037/0033-2909.113.2.279

Ersan, Ö., Üzümcüoğlu, Y., Azık, D., Fındık, G., Kaçan, B., Solmazer, G., ... \& Xheladini, G. (2020). Cross-cultural differences in driver aggression, aberrant, and positive driver behaviors. Transportation Research Part F: Traffic Psychology and Behaviour, 71, 88-97. doi:10.1016/j. trf.2020.03.020

Granié, M., Pannetier, M., \& Guého, L. (2013). Developing a self-reporting method to measure pedestrian behaviors at all ages. Accident Analysis and Prevention, 50, 830-839. doi:10.1016/j. aap.2012.07.009

Gras, M. E., Sullman, M. J. M., Cunill, M., Planes, M., Aymerich, M., \& Font-Mayolas, S. (2006). Spanish drivers and their aberrant driving behaviors. Transportation Research Part F: Traffic Psychology and Behaviour, 9, 129-137. doi:10.1016/j.trf.2005.09.004

Guého, L., Granié, M. A., \& Abric, J. C. (2014). French validation of a new version of the Driver Behavior Questionnaire (DBQ) for drivers of all ages and level of experiences. Accident Analysis and Prevention, 63, 41-48. doi:10.1016/j.aap.2013.10.024

Herrero-Fernández, D., Macía-Guerrero, R., Silvano-Chaparro, L., Merino, L., \& Jenchura E. C. (2016). Risky behavior in young adult pedestrians: Personality determinants, correlates with risk perception, and gender differences. Transportation Research Part F: Traffic Psychology and Behaviour, 36, 14-24. doi:10.1016/j.trf.2015.11.007

Lawton, R., Parker, D., Manstead, A. S. R., \& Stradling, S. G. (1997). The role of affect in predicting social behaviours: The case of road traffic violations. Journal of Applied Social Psychology, 27, 1258-1276. doi:10.1111/j.1559-1816.1997.tb01805.x

Lefever, S., Dal, M., \& Matthiasdottir, A. (2007). Online data collection in academic research: Advantages and limitations. British Journal of Educational Technology, 38(4), 574-582. doi:10.1111/j.1467-8535.2006.00638.x

Martinussen, L. M., Møller, M., \& Prato, C. G. (2014). Assessing the relationship between the Driver Behavior Questionnaire and the Driver Skill Inventory: Revealing sub-groups of drivers. Transportation Research Part F: Traffic Psychology and Behaviour, 26, 82-91. doi:10.1016/j. trf.2014.06.008

McIlroy, R. C., Plant, K. L., Jikyong, U., Hoài, N. V., Bunyasi, B., Kokwaro, G. O., ... \& Stanton, N. A. (2019). Vulnerable road users in low-, middle-, and high-income countries: validation of a pedestrian behaviour questionnaire. Accident Analysis and Prevention, 131, 80-94. doi:10.1016/j. aap.2019.05.027

Nordfjærn, T., \& Şimşekoğlu, Ö. (2013). The role of cultural factors and attitudes for pedestrian behaviour in an urban Turkish sample. Transportation Research Part F: Traffic Psychology and Behaviour, 21, 181-193. doi:10.1016/j.trf.2013.09.015 
Öz, B., Özkan, T., \& Lajunen, T. (2013). An investigation of professional drivers: Organizational safety climate, driver behaviours and performance. Transportation Research Part F: Traffic Psychology and Behaviour, 16, 81-91. doi:10.1016/j.trf.2012.08.005

Öz, B., Özkan, T., \& Lajunen, T. (2014). Trip-focused organizational safety climate: Investigating the relationships with errors, violations and positive driver behaviours in professional driving. Transportation Research Part F: Traffic Psychology and Behaviour, 26, 361-369. doi:10.1016/j. trf.2014.03.004

Özkan, T., \& Lajunen, T. (2005). A new addition to DBQ: Positive Driver Behaviours Scale. Transportation Research Part F: Traffic Psychology and Behaviour, 8, 355-368. doi:10.1016/j. trf.2005.04.018

Özkan, T., \& Lajunen, T. (2011). Person and environment: Traffic culture. In B. E. Porter (Ed.), Handbook of traffic psychology (pp.179-192). San Diego, CA: Elsevier.

Öztürk, İ., \& Özkan, T. (2018). Genç sürücülerde sürücü becerileri ve sürücü davranışları arasındaki ilişki [The relationship between driving skills and driver behaviors among young drivers]. Trafik ve Ulaşım Araştırmaları Dergisi, 1(2), 1-15. doi:10.38002/tuad.418260

Papadimitriou, E. (2016). Towards an integrated approach of pedestrian behaviour and exposure. Accident Analysis and Prevention, 92, 139-152. doi:10.1016/j.aap.2016.03.022

Papadimitriou, E., Lasarre, S., \& Yannis, G. (2016). Pedestrian risk taking while road crossing: A comparison of observed and declared behaviour. Transportation Research Procedia, 14, 43544363. doi:10.1016/j.trpro.2016.05.357

Parker, D., \& Stradling, S. (2001). Influencing Driver Attitudes and Behaviour: DETR Road Safety Research Report (Report no.17). London: Department of the Environment, Transport and the Regions.

Qu, W., Zhang, H., Zhao, W., Zhang, K., \& Ge, Y. (2016). The effect of cognitive errors, mindfulness, and personality traits on pedestrian behavior in a Chinese sample. Transportation Research Part F: Traffic Psychology and Behaviour, 41, 29-37. doi:10.1016/j.trf.2016.06.009

Reason, J., Manstead, A., Stradling, S., Baxter, J., \& Campbell, K. (1990). Errors and violations on the roads: A real distinction? Ergonomics, 33, 1315-1332. doi:10.1080/00140139008925335

Scott-Parker, B., Watson, B., King, M. J., \& Hyde, M. K. (2014). Young novice drivers and the risky behaviours of parents and friends during the Provisional (intermediate) licence phase: A brief report. Accident Analysis and Prevention, 69, 51-55. doi:10.1016/j.aap.2013.11.016

Scott-Parker, B., Watson, B., King, M. J., \& Hyde, M. K. (2015). "I would have lost the respect of my friends and family if they knew I had bent the road rules": Parents, peers, and the perilous behaviour of young drivers. Transportation Research Part F: Traffic Psychology and Behaviour, 28, 1-13. doi:10.1016/j.trf.2014.10.004

Shen, B., Qu, W., Ge, Y., Sun, X., \& Zhang, K. (2018). The relationship between personalities and selfreport positive driving behavior in a Chinese sample. PLoS One, 13(1), e0190746. doi:10.1371/ journal.pone.0190746

Solmazer, G., Azık, D., Fındık, G., Üzümcüoğlu, Y., Ersan, Ö., Kaçan, B., .. \& Pashkevich, M. (2020). Cross-cultural differences in pedestrian behaviors in relation to values: A comparison of five countries. Accident Analysis \& Prevention, 138, 105459. doi:10.1016/j.aap.2020.105459

Stephens, A. N., \& Fitzharris, M. (2016). Validation of the Driver Behaviour Questionnaire in a representative sample of drivers in Australia. Accident Analysis \& Prevention, 86, 186-198. doi:10.1016/j.aap.2015.10.030

Sümer, N., Lajunen, T., \& Özkan, T. (2002, 8-12 May). Sürücü davranışlarının kaza riskindeki rolü: Ihlaller ve hatalar [The role of driver behaviours at the risk of accident: Violations and errors]. Traffic and Road Safety International Congress, Gazi Üniversitesi, Ankara, Turkey. 
Şimşekoğlu, Ö. (2015). How do attitudes, personality traits, and driver behaviors relate to pedestrian behaviors?: A Turkish case. Traffic Injury Prevention, 16(1), 84-89. doi:10.1080/15389588.2014. 880785

Şimşekoğlu, Ö., Nordfjærn, T., Zavareh, M. F., Hezaveh, A. M., Mamdoohi, A. R., \& Rundmo, T. (2013). Risk perceptions, fatalism and driver behaviors in Turkey and Iran. Safety Science, 59, 187-192. doi:10.1016/j.ssci.2013.05.014

Tabachnick, B. G., \& Fidell, L. S. (2013). Using multivariate statistics (6th ed). Northridge, CA: Pearson.

Taubman-Ben-Ari, O., \& Shay, E. (2012). The association between risky driver and pedestrian behaviors: The case of Ultra-Orthodox Jewish road users. Transportation Research Part F: Traffic Psychology and Behaviour, 15, 188-195. doi:10.1016/j.trf.2011.12.005

Taubman-Ben-Ari, O., Eherenfreund-Hager, A., \& Prato, C. G. (2016). The value of self-report measures as indicators of driving behaviors among young drivers. Transportation Research Part F: Traffic Psychology and Behaviour, 39, 33-42. doi:10.1016/j.trf.2016.03.005

Tom, A., \& Granié, M. A. (2011). Gender differences in pedestrian rule compliance and visual search at signalized and unsignalized crossroads. Accident Analysis and Prevention, 43, 1794-1801. doi:10.1016/j.aap.2011.04.012

Ulleberg, P., \& Rundmo, T. (2003). Personality, attitudes and risk perception as predictors of risky driving behaviour among young drivers. Safety Science, 41(5), 427-443. doi:10.1016/S09257535(01)00077-7

Üzümcüoğlu, Y., \& Özkan, T. (2019). Traffic climate and driver behaviors: Explicit and implicit measures. Transportation Research Part F: Traffic Psychology and Behaviour, 62, 805-818. doi:10.1016/j.trf.2019.03.016

Üzümcüoğlu, Y., Özkan, T., Wu, C., \& Zhang, H. (2019). How drivers perceive traffic? How they behave in traffic of Turkey and China?. Transportation Research Part F: Traffic Psychology and Behaviour, 64, 463-471. doi:10.1016/j.trf.2019.06.006

World Health Organization (2018). Global status report on road safety 2018. Retrieved from: https:// www.who.int/violence_injury_prevention/road_safety_status/2018/en/

Xu, J., Ge, Y., Qu, W., Sun, X., \& Zhang, K. (2018). The mediating effect of traffic safety climate between pedestrian inconvenience and pedestrian behavior. Accident Analysis and Prevention, 119, 155-161. doi:10.1016/j.aap.2018.07.020

Xu, J., Liu, J., Qu, W., Ge, Y., Sun, X., \& Zhang, K. (2018a). Comparison of pedestrian behaviors between drivers and non-drivers in Chinese sample. Transportation Research Part F: Traffic Psychology and Behaviour, 58, 1053-1060. doi:10.1016/j.trf.2018.05.034

Yıldırım, Z. (2007). Religiousness, conservatism and their relationship with traffic behaviours. (Unpublished Master's Thesis). Middle East Technical University, Ankara, Turkey.

Y1lmaz, Ş., Öz, B., \& Özkan, T. (2019) Profesyonel sürücülükte sürücü davranışlarına yönelik nitel bir çalışma [A qualitative study of driving behaviors of professional driving]. Trafik ve Ulaşım Araştırmaları Dergisi, 2(1), 51-65. doi:10.38002/tuad.525441 


\section{APPENDIX A.}

Turkish Translation of Pedestrian Behaviour Scale Items

\section{Transgression}

Item 13. 50 metreden daha yakında bir yaya geçidi olduğu halde, yaya geçidinin olmadığı bir yerden karşıdan karşıya geçerim.

Item 21. Bazen en yakın yaya geçidi çok uzakta ise karşıdan karşıya yaya geçidinin olmadığı bir yerden geçerim.

Item 25. Etrafta karşıdan karşıya yaya geçidini kullanmadan geçen birçok kişi varsa onları takip ederim.

Item 12. Trafik 1şı̆̆ yayalara kırmızı yandığı halde karşıdan karşıya geçerim.

Item 24. Daha emniyetli olmalarına rağmen kullanımları zor olduğu için çoğunlukla üstgeçitlerden geçmem.

Item 11. Birçok kişi öyle yaptığı için karşıdan karşıya emniyetsiz yerlerden geçerim.

Item 23. Çoğunlukla karşıdan karşıya yaya geçidinin olmadığı yerlerden geçerim çünkü yeteri sayıda yaya geçidi yoktur.

Item 6. Bazen trafikte bir boşluk olduğunu görünce bu firsatı değerlendirip hemen karşıdan karşıya geçmeye çalışırım.

Item 2. Karşıdan karşıya geçmem için yakında daha emniyetli yerler olsa da park etmiş araçların arasından geçerim.

Item 28. Eğer karşıdan karşıya kırmızı 1şıkta geçen birçok kişi var ise, ben de onlarla birlikte geçerim.

Item 10. Bazen kaldırımda yürümek yerine yolda yürürüm.

*Item 14. Karşıdan karşıya geçmek için yürümeye başlarım ama karşıdan gelen araçlardan kaçmak için koşmak zorunda kalırım.

\section{$\underline{\text { Lapses }}$}

Item 9. Karşıdan karşıya geçerken telefonla konuşuyorsam yolu kontrol etmeyi unuturum.

Item 5. Bazen başka bir şey düşündüğüm için yolu kontrol etmeyi unuturum.

Item 7. Bazen acelem olduğu için yolu kontrol etmeden koşarak geçerim.

Item 1. Bazen karşıdan karşıya geçerken yanımdakilerle konuştuğum için yola dikkatli bir şekilde bakmayı unuturum. 
*Item 18. Bazen birkaç sokağ1 ve kavşağı trafiğe dikkat etmeden geçtiğimi fark ederim.

Item 29. Bazen alkollü olduğum zamanlarda karşıdan karşıya yolu dikkatli bir şekilde kontrol etmeden geçerim.

*Item 30. Alkol aldığım zamanlarda, yaya geçitlerini daha az kullanırım.

*Item 3. Bazen karşıdan karşıya emniyetli bir şekilde geçebileceğimi düşünürüm ama karşıdan gelen aracın düşündüğümden daha hızlı geldiğini fark ederim.

\section{Aggressive Violations}

Item 20. Bir yol kullanıcısına (yaya, sürücü vs.) kızar ve ona el-kol hareketi yaparim.

Item 17. Bazen bir sürücüyü rahatsız etmek için yolu çok yavaş geçerim.

Item 19. Bir yol kullanıcısına (yaya, sürücü vs.) kızar ve ona hakaret ederim.

*Item 16. Yolda gelen araçlar olsa bile karşıdan karşıya geçerim çünkü benim için duracaklarını düşünürüm.

*Item 26. Bana doğru gelen arabalar olsa bile trafik 1şığı sarıya döndüğünde karş1dan karşıya geçmeye başlarım.

*Item 8. Trafik olsa da olmasa da karşıdan karşıya geçerim çünkü trafikteki araçlar benim için durmalıdırlar.

\section{Positive Behaviours}

Item 22. Diğer yayalarla birlikte yürüdüğümde, karşıdan gelenleri rahatsı etmemek için dar kaldırımlarda tek sıra halinde yürürüm.

Item 4. Karşıdan gelen yayaları rahatsız etmemek için kaldırımın sağından yürürüm.

Item 27. Karşılaştığım yayalara yol vermek için dururum.

*Item 15. Yol hakkı bende olsa bile, arkasından gelen başka araç yoksa, bir aracın benden önce geçmesine izin veririm.

*Item 31. Karanlıkta yürürken yansıtıcı kıyafetler kullanarak diğerlerinin beni daha rahat görmesini sağlarım.

Note. * Items removed due to cross-loading or loading on to single factor with a cutoff below .50. Factor loadings $<.50$ are suppressed. 